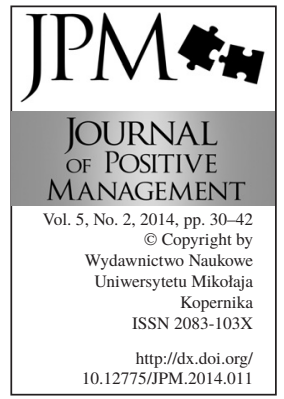

\title{
EMPLOYEE PARTICIPATION IN MANAGEMENT. CASE STUDY OF A DEMOCRATIC ORGANIZATION - MONDRAGÓN CORPORATE COOPERATIVA
}

\author{
Aleksandra Bławat \\ Institute of Psychology, Jagiellonian University, Kraków, Poland, \\ e-mail: aleksandra.blawat@uj.edu.pl
}

\begin{abstract}
Purpose: The present paper is a critical analysis of Mondragón Corporate Cooperativa (MCC), a company known as one of the largest organizations in the world, which for many years has been successfully applying employee participation in management. The main purpose of this article is to present a literature review of the field of participatory management and to analyze a real example which shows how the functioning of a democratic organization looks like, what impact does it have on employees and the business.
\end{abstract}

Methodology: Case study analysis was conducted based on interviews with employees, data analysis and observation.

Findings: Democracy in MCC is not only marked by employee ownership, profit-sharing among all members of the organization and transparency of all information including remuneration, but also by democratic selection of governing bodies and making most of important decisions by voting, in which all members of the organization participate. All of these characteristics have significant influence on the attitude of employees towards the organization, their perception of the workplace and also the specificity of problems that arise in the organization.

Originality of the paper: The practices of employee participation in management and organizational decision making have been relatively popular over the last years. However, in the literature it is hard to find examples which investigate how the organization has to be designed in order to allow employees active participation. The originality of this paper is ensured by detailed description of a real company where participation in management is implemented.

Keywords: employee participation in management, Mondragón, organizational democracy, cooperatives

Paper Type: Case study

\section{Introduction}

The purpose of this article is to present a case study of one of the world's most famous democratically governed organizations- Mondragón Corporate Cooperativa (MCC) localized in the Basque Country in Spain. The analysis 
is based on the experience and knowledge gained by the author of this article during half-year research stay in the MCC, which was a great opportunity to make many observations of democratically managed organization and conduct dozens of interviews with employees and retired members of the cooperatives. Additionally, the present case study is supported by the literature review of theories of participatory management and democracy at the workplace, on which the organizational system in Mondragón is based. The analysis shows how the company is designed and how it is organized in order to allow all employees to participate in everyday management: in decision making, in setting organizational goals, in the process of employing new members and choosing the representatives of the company, to name just a few. Criticism of such approach together with some problems identified in MCC and their mechanisms already described in the literature are also provided.

\section{Literature review}

The idea of a key role of democratic rules in the organizational world has a long and turbulent history. However recently, over the last 20-30 years, distribution of power in the organization has become remarkably popular (Butcher and Clarke, 2002). Growing interest in democratic practices, based on classic works of McGregor (1960) and Maslow (1954), is visible not only in the current scientific literature, but also in organizational practices both abroad (e.g. Erdal, 2008; Stack and Burlingham, 1994; Semler, 1998) and in Poland (e.g. Bławat and Drobny, 2011).

According to Butcher and Clarke (2002) democratic organizations can be described by decentralization of authority and shared responsibility, which leads to the development of smaller, self-organizing, autonomous units within the organization. It is also reported that employees of democratic organizations have the sense of psychological ownership (Pierce et al., 2001) with respect to organizational activities that depend on their individual contribution and knowledge (Butcher and Clarke, 2002). However, above all, traditional theory of democracy presupposes a broad and direct participation of the community members in the social system (Dachler and Wilpert, 1978).

The concept of the employee participation in management may take many forms - starting from more generic solutions, such as employee ownership, ending on single practices, such as information sharing. Neither participation in management, nor democracy in the organization are zero-one phenomenon (Rivera-Batiz and Rivera-Batiz, 2002). Participation as a multidimensional concept was also argued by Cotton et al. (1988), who distinguished several types of participation in the organization: representative, consultative, short-term, informal participation, participation in decision making and employee ownership. When those types of participation were compared in terms of their effectiveness, it turned 
EMPLOYEE

PARTICIPATION

IN MANAGEMENT

Aleksandra Bławat out that they produce different results. This conclusion could explain why there are so many conflicting results of different studies on participation effectiveness. Thus, some reports claim the positive impact of participation on job satisfaction, productivity, and other dimensions of performance (e.g. Mohr, 1977), others - the opposite - the absence of such influence (e.g. Lischeron and Wall, 1975). Cotton et al. (1988) pointed out that, for example, informal participation and employee ownership, as opposed to short-term participation, are effective both in terms of job satisfaction and productivity. Representative participation, however, does not increase productivity, but increases employee satisfaction.

Discussing short-term participation, it is worth mentioning that often isolated acts of promoting employee participation in organizational processes are used to bring closer traditionally managed organizations towards more democratic ones. However, very often they are designed and implemented only for instrumental reasons- to increase productivity and reduce absenteeism. When employees become beneficiaries of such organizational changes only on the surface, it is easy to accuse the organization of cynicism, duplicity, and creating the illusion in the organization (Butcher and Clarke, 2002). Therefore, a complete participation is possible only in autonomous organizations (Mazur, 1969), or in those that provide employees with both the legal property of the company, as well as the right to participate in the process of decision-making. Stocki, Prokopowicz and Żmuda (2012) point out that recognizing employees' dignity as free persons is the key to success of participatory systems. If the employees are co-owners, they think and act as co-owners (Pfeffer, 1998) and become entrepreneurs, who act more responsibly and who are more interested in the results of their company (Bakan et al., 2004). Mondragón Cooperative Corporation is said to be a complete democratic organization. In the following section of the article, the analysis of democratic practices used in MCC and employee's reactions to them will be provided.

\section{Research methods}

The present article uses case study method. The analysis of the organization is based on few sources: 48 interviews conducted with members of cooperatives and retired employees, half-year participatory observation of cooperatives and analyses of the data about MCC.

\section{Analysis}

\subsection{The history of Mondragón}

According to Butcher and Clarke (2002), there are only few truly democratic organizations and Mondragón Corporate Cooperativa is one of them. Therefore, they claim that when one observes an example of such organization, it seems to be more an interesting experiment rather than a real company with real employees, 
from whom one could gain valuable experience, tips and ready-made solutions to common problems. However, Mondragón Group is one of the most important counter-arguments against the claims of some practitioners that workplace democracy is only demagogy without reference to reality.

Mondragón Corporate Cooperativa is a group of 256 organizations, around 110 of which are cooperatives. Companies belonging to MCC are spread all over the world and they operate in four different areas of business activity: finance, industry, retail and education (Irizar and MacLoad, 2010). MCC headquarters is located in the town of Mondragón in heart of the Basque Country. The location is symbolic, because Mondragón is considered as being the cradle of the Basque cooperative movement. The story of the movement began in 1941, when a young priest José María Arizmendiarrieta came to this small village in the valley of the Basque Mountains to take care of the local youth. During this time, the Basque Country was oppressed by the consequences of Spanish civil war. Rampant poverty was a result of drastic increase in unemployment. In these difficult times, after starting a professional school, in 1956, the first cooperative - Ulgor was set up. It was founded by five priest's pupils, thanks to his inspiration and assistance (Cancelo, 1999). Soon it became a model for hundreds of followers. Initially, Ulgor was engaged in the production of paraffin heaters, eventually it evolved into a cooperative called Fagor, which today is a group of industrial companies affiliated to MCC. After the success of Ulgor, cooperatives in various industries in the area of Mondragón were developing very dynamically (Casadesus-Masanell and Khanna, 2003). A cooperative bank, university, new factories, consulting firms, and distributing companies emerged. Finally, MCC has grown to the size of a company employing 85322 people and has become the largest business organization in the Basque Country and the seventh largest in Spain [1]. With total assets of $€ 33$ billion in 2010, MCC is the most successful co-operative system in the world (Wright et al., 2011). And all this has been accomplished with almost 40,000 co-owners who on a daily basis participate in managing the organization.

\subsection{MCC's rules}

The uniqueness of this organization is best illustrated by the basic principles, which are applied by all cooperatives belonging to MCC and which are the foundation of the cooperative management model (Irizar and MacLeod, 2012). Rules described below depict precisely the design of the organization, which allows employees to participate in management.

I. The first rule- "Open admission"- assumes that every employee of the cooperative has the right to become a member, thus, to become a co-owner of the company where he or she works (Irizar and MacLeod, 2012). Members are approved by the Supervisory Board. Naturally, whether the employee becomes a member depends on the current financial condition of the cooperative and of 
EMPLOYEE

PARTICIPATION

IN MANAGEMENT

Aleksandra Bławat his or her own desire to join the group of co-owners. However, in Mondragón it is difficult to find a person who would not like to become a member of a cooperative. Moreover, in order to become a member, a few specific conditions must be met (e.g. have one or two years of tenure in the cooperative). Those particular conditions are specified by each cooperative. Still, there are some common rules- in each cooperative, an employee who is becoming a co-owner must pay the so-called contribution, which is equal for all members, regardless of their position in the hierarchy. Typically it is the amount of several thousand euros. If the employee is not able to invest such amount of money at one time, it is possible to pay it by withdrawing a percentage of monthly pay. This solution is a kind of investment of capital, because each year part of income earned by the organization is added to each employee's so-called "booklet" (Spanish: cartilla). Of course, if the cooperative loses, it is reflected in the negative balance. Yet typically it is very beneficial investment for the future. Whole capital collected by employees from the beginning of their employment is paid to them when they leave the company or retire. Theoretically, it may happen that the workers who leave the company do not earn anything because the company for a long time had a very poor financial results. However, in practice, such situations do not happen, because MCC developed mechanisms that protect from such circumstances (an example of such mechanism is described within the "inter-cooperation" rule). Therefore, the most common situation is to retire with an additional capital of tens or even hundreds of thousands of euros.

II. Another principle in MCC is "Democratic organization". It is summarized by the popular say in Mondragón- "One voice- one vote" (Spanish: un voz- un voto), which means that regardless of the position occupied in the organization, all employees have exactly the same right to participate in voting and each co-owner has only one vote of equal weight (Irizar and MacLeod, 2012). It applies to all voting that take place in the company- either the voting for the Supervisory Board for a four-year term of office, or the voting on the reduction of wages in the face of crisis. Democracy is also reflected in minimized organizational hierarchy, which is confirmed by one of MCC's worker's comments: "Actually, hierarchy does not exists in here (...). Relations with my boss are as with any other employee. In general, I don't have the impression that he is the boss, because the truth is that in one project I am the coordinator, in the other- my boss." Another employee adds: "It seems to me, that in other companies sometimes happens that you just have to shut up when the boss is approaching. In here-not at all. What's more, people in here simply say to their bosses if they do not like the way they carry out their tasks."

III. "The sovereignty of labor" is another rule, which emphasizes the importance of work itself, as well as the importance of creating new workplaces and maintaining those already existing (Irizar and MacLeod, 2012). In practice 
this rule manifests itself in the fact that dismissals of MCC members occur only in extreme cases. A member of the cooperative cannot be fired because of financial reasons, which is why employees very often say that working in a cooperative induces the sense of security. "An important aspect of being a member of the cooperative is a sense of security when it comes to work. In the history of Mondragón, as far as I know, no member has never been fired. It gives a great sense of security"- argues one of cooperative's employee. This rule shows that cooperatives give a lot of importance to the development and support of the local community. As being a part of the society, cooperatives are responsible for its future. Interestingly, the Basque Country, the economy of which is largely based on the cooperative sector, is the proverbial green spot on the map of Spanish economic crisis- in 2012 the unemployment rate in the Basque Country was$14,87 \%$ whereas in whole Spain $-25,03 \%$ [2]. According to the report generated by Confederation of the Basque Cooperatives [3], in the current crisis, a steep rise in the number of new cooperatives can be observed. In the Basque Country itself each year about a hundred new cooperatives are created. Mondragón Group thus shows that democracy at work- often considered impractical- can be an effective way to face economic crisis.

IV. Another principle underlying the functioning of the MCC is "Instrumental and subordinate nature of capital". It means that revenue is treated as a business tool, rather than an aim itself (Irizar and MacLeod, 2012). Indeed, it is one of the main economic assumptions of the cooperative. The objective is not to maximize the profit, but to maintain and create new jobs. The profits of course must be maximized, but not in order to enrich the current owners (i.e. particular employees of the cooperative), as it usually takes place in joint stock companies, but to enrich the community by transferring capital to investments of social character. "I must admit that it is very hard to see that someone loses a job. It's my philosophy of life that money is not everything, it is not an end-in-itself. And in the cooperatives money is considered in the same way-it is treated only as a tool to achieve other important goals"- says one of the members of the cooperative.

V. The rule, "Participative management" is the one, which is the essence of democracy in cooperatives, as it gives each co-owner the right to participate in everyday organizational life and in all ongoing organizational processes (Irizar and MacLeod, 2012). This is reflected both in the right to vote and make decisions, as well as in the access to information about the financial condition of the organization. Flow of information is perceivable in Mondragón not only within the formal knowledge about the organization, but first of all- in the real interest of employees in what is happening in each department and how does this influence company's financial results. An interesting illustration of the knowledge which employees poses about their organizations was shown to the author of this article during the tour of two cooperatives. In the first one the "guide" was the chairman 
EMPLOYEE

PARTICIPATION

IN MANAGEMENT

Aleksandra Bławat

of the Supervisory Board. While walking through the factory, he presented an amazing knowledge of each tool and each screw that is used in the production, even though he hasn't been using it at all in his daily work. On the other hand, in the second cooperative, the "guide" was a lower-level employee, who was explaining the work carried out in the factory, characterizing the situation of the company in the global market, listing the chain of suppliers, and enumerating the key customers and potential mechanisms of protection against competitors. Those two visits have shown that employees from all levels of organizational hierarchy possess valuable knowledge about the whole scope of organizational activity, both internal and external.

VI. One of the most interesting and also the most controversial rules in the MCC is "Wage solidarity" (Irizar and MacLeod, 2012). It is based on the golden rule of cooperatives in Mondragon, which is the assumption that the disproportion in wages between an employee who earns the least and an employee who earns the most cannot be higher than the ratio of 1:6 (in the past, this rule was based on an even lower ratio- 1:3). It is hard to compare it with the local joint stock companies, where, as it is said in Mondragón, the ratio reaches even up to 1:150. Consequently, in MCC you can meet many employees who could earn several or even dozens of times more in competitive joint-stock companies, but for various reasons they decide to work in a cooperative and earn less. Perhaps this is due to the fact that money is a factor that increases the level of happiness only to a certain point, after which it remains at a constant high level, regardless of further increase in salary. This relation was noted by Warr (2007) in his "vitamin" concept of happiness. He argues that if the income reaches a certain satisfactory threshold, additional revenue does not increase the feeling of job satisfaction any more. This relation was originally found by Herzberg (1959), who claimed that there are two factors which influence job satisfaction: hygiene factors (like proper working conditions, salary, etc.), which assure lack of job dissatisfaction, and motivator factors (like recognition, responsibility, etc.) which may facilitate job satisfaction. One of the retired employees of the cooperative indicated an interesting example illustrating what effect causes the golden rule. According to him, in the comparable private companies manager's salaries are up to $60 \%$ higher than in the cooperative, whereas the wages of employees in the lowest positions are about $25 \%$ lower than in the cooperatives. Nevertheless MCC is not about full egalitarianism, it is about finding a solution, which will overcome extreme and unjustified differences in salaries between employees in different positions in the company.

VII. The next rule which characterizes the functioning of the MCC is the socalled "Inter-cooperation". It refers to the relations between the Group Mondragón and other companies operating in the Basque Country and around the world, as well as to cooperative movements that promote the development of cooperatives. Above all, however, this rule applies to internal relations between cooperatives 
of MCC. As a result, it implies the possibility of relocating employees from one cooperative to another in case of a need of redundancies in one of them (Cancelo, 1999). If any of the cooperative is facing financial problems, the remaining cooperatives decide in voting, whether to reduce their salaries by a few percent to help cooperatives in the financial crisis. This is also another example of how they participate in making decisions about important organizational issues. Usually, such aid is granted, in light of the principle of solidarity. Employees are aware that one day the situation can be reversed and they might be the ones who may need a financial support from other cooperatives. It was confirmed by one of them: "I prefer that we all gave up our additional pay, which we receive, or we earned a little less, than any of us would have to lose the job."

VIII. Another of the rules- "Social Transformation"- emphasizes the importance of the impact of cooperatives on the local community and is deeply rooted in the Basque culture. Cooperatives in Mondragón are highly committed to promoting economic and social development of the society where they operate. In practice, it can be observed in the distribution of cooperatives' income: $45 \%$ goes to the so-called reserves, $45 \%$ goes to abovementioned booklets and $10 \%$ goes for the investment in local initiatives.

IX. Another cooperative principle- "Universality"- emphasizes the fact that Mondragón Group, as an act of its vocation, preaches solidarity with those who are working for economic democracy and the social economy (Irizar and MacLeod, 2012).

X. The rule "Education", in turn, stresses the importance of knowledge, as a complex system of ideas and concepts, which is key to the development of the society. Interestingly, University of Mondragón is also a cooperative, as well as many of the research institutions established around the university (Irizar and MacLeod, 2012).

All above mentioned principles of the organization have a great impact on employees' attitudes towards their work, their job satisfaction, and on how employees perceive their work- whether they identify themselves with the organization and whether they feel responsible for their work and the company. This was confirmed by the words of one of the employees of the cooperative: "I feel that this is my own company. My husband has his business, his own small business, and I have my own business. Together with other employees, of course, but it is also mine. And I think that we all contribute to its success. And when I say everyone, I mean everyone- both the person who works at the reception desk, as well as the director. The role of each of us is of the same importance."

An interesting study on job satisfaction was conducted in one of the organizations belonging to the MCC (Arando, 2013). Due to the ongoing organizational changes one company in MCC was employing three groups of employees: (1) workers who did not have the opportunity to become a member 
EMPLOYEE

PARTICIPATION

IN MANAGEMENT

Aleksandra Bławat of the cooperative, as they were working in a joint-stock company owned by the cooperative, (2) employees who have become members of cooperatives because of organizational changes- transformation of joint stock companies belonging to cooperatives into cooperatives, and (3) employees who have been working since the beginning as members of the cooperative. The study measured the level of satisfaction of employees in those three groups. Interestingly, the highest level of satisfaction was observed among employees who became members of the cooperative and previously had worked in joint-stock companies, instead of those who have been members of the cooperative from the very beginning. After a series of interviews with employees researchers found that this group was most pleased with their work, because its members had the opportunity to make a comparison between the situation of the worker of a joint-stock company and the member of a cooperative. As they explained- cooperative members who have never worked in a joint-stock company had no possibility to compare and had already become accustomed to the "luxury" of participation in decision making, having control over the organization and sharing the profits.

\subsection{A critical perspective}

For a number of co-owners, the system which is applied in cooperatives in Mondragón makes their job gain a deeper sense. However, this is not the rule applicable to all employees. Like any organization, Mondragón also deals with many problems- not only those of economic nature, but also organizational ones. While carefully analyzing the specificity of cooperative management model, it is hard to find something to criticize. The problem and potential areas of criticism arise when the model is applied in practice. Employee participation in management is really difficult to be implemented in the organization and- as it is shown by the example of MCC-it may cause unpredictable side effects. As emphasized by employees themselves, in many areas there is a visible gap between the idea of cooperativism and everyday life. Not surprisingly, this difference is noticed in particular among employees who work on the lowest levels of the organizational hierarchy. As the case of Mondragón Group shows, the division between "us and them" stemming from the distribution of power, can be perceived even in a democratic organization. As it is clear from interviews conducted with employees, perception of injustice and lack of influence on organizational life is much stronger among blue-collar employees. This is also the group of employees who most frequently manifest their dissatisfaction arguing that even though they agree with the cooperative's basic principles, their application in daily life leaves a lot to be desired.

The greatest paradox of cooperatives is that the more prosperous they are, the more difficult it is to manage them. This is because MCC's better financial results are strictly related to the creation of new vacancies. As a result, it is more 
difficult to apply in practice participative management in a way that each member of the cooperative would feel as co-owner. Organizational hierarchy automatically becomes more complex, personal relationships lose their force, and people who have greater impact on organizational decisions are gaining more and more power. This may be explained by Meister's observation (1974, after: Bakaikoa et al., 2004), which has shown that democratic organizations have a life cycle and at reaching some point they are dominated by the ruling elite. Also Michels' (1915) iron law of oligarchy clearly states that "the formation of oligarchies within the various forms of democracy is the outcome of organic necessity and consequently affects any organization (...)" (p. 402). The problem of the size and internal relations was also admitted by the employees of the cooperative who compare the present situation with the times, when the company consisted of only a few dozens of employees. "There used to be more closeness between colleagues. Now each of us goes on their own way"- says one of the employees.

MCC is trying to deal with the problem of the size by dividing the rapidly evolving and growing companies into smaller units. As a result, industry groups which consist of smaller companies dealing with more specified products or services, are created (for example Ulma Group consists of 8 autonomous cooperatives, such as: Ulma Construcción, Ulma Packaging, Ulma Agricola, etc.; hiring in total around 4300 employees, $93 \%$ of which are members of the cooperatives). However, as another employee adds: "Of course, relationships in a big company are very different, but we cannot create a reality in which all of our cooperatives have 10-12 people. We have to compete with companies that employ 2,000 workers."

Such conclusions seem to be confirmed by the results of the studies conducted by Cabrera et al. (2001). The studies based on data collected in more than 5000 organizations from 10 European countries, confirmed that the larger the organization, the more difficult it is to participate in management. Paradoxically, however, many researchers suggest that larger companies use participatory practices more often, than the smaller ones. Cabrera et al. (2001) in their article cite the results of several years of research conducted in the UK by Hyman and Mason (1995). According to this research, there is a positive linear relation between the size of the organization and the number of initiatives taken by the employees. Presumably, this is because larger organizations are more willing to use innovative practices and they more often try to solve motivational problems of their employees using participatory management.

In the literature, there can also be found a phenomenon known as degeneration of cooperatives (Bakaikoa et al., 2004). It indicates that in the long run cooperatives fail to maintain the democratic principles of governance under internal pressures and the pressure of the free-market environment. In the case of MCC external pressure is particularly strong because of the current economic crisis in the whole 
EMPLOYEE

PARTICIPATION

IN MANAGEMENT

Aleksandra Bławat of Spain. Mondragón Group, looking for ways to survive, adopted a model of expansion outside the Basque Country, which is based on establishing joint-stock companies. For members of the cooperative it is very problematic, because on one hand, such step seems to be necessary for the organization to survive, on the other hand, it involves a loss of cooperative spirit and it breaks the rules which MCC has always been committed to follow.

As noted by Grady (1990), another problem in participative organizations is the inoculation of democratic values among employees who represent individualistic and non-participative values. This problem is also visible in Mondragón. Not all employees start their careers in a cooperative filled with cooperative spirit. There are those who in the course of work, by the influence of organizational culture, become true members of cooperatives. However, there are also employees who are completely resistant to assimilation and who do not identify with the culture of the cooperative. As confirmed by one of the cooperative members: "It seems to me that we are facing a crisis of values in general. We can also observe a loss of the cooperative values. Nowadays, there is no such identification with the project... People are happy to have a steady job and they think they don't need to devote more. It is the separation of a man from the organization."

\section{Conclusions}

In Mondragón it is often said: "We are not perfect, but we are perfectible". As shown in the previous part of the article, difficulties faced in MCC arise both from the level of group dynamics and from the level of business strategy. Though, it has to be admitted that MCC had invested a lot of effort in complex and participative organizational design, which gives the possibility of meeting high, often excluding expectations of employees and the business itself. On the top of that, such design helps the organization to maintain democratic practices, as one of MCC's employees stated: "Even with so many defects and problems, we are still more democratic than any joint-stock company".

Other secret to overcome problems specific for such companies is simple loyalty to organizational values, which in case of MCC are the essence of democratic organization. They indicate: co-operation (by acting like owners of the company), participation (by being committed to every-day management), social responsibility (by being solidary with others), and innovation (by focusing on improvements). Throughout the whole very long history of $\mathrm{MCC}$, which consisted of periods of deep crisis and fruitful prosperity, employees were loyal to their values and treated them as the borderline that is never crossed. This has built the internal power of cooperative, which is naturally protecting itself from collapsing under the burden of economic crises or other difficulties.

Next valuable lesson learned from MCC's experience is the importance of trust in employees, which manifests itself in sharing responsibility, giving freedom 
to employees and respecting them. Trust in people is the characteristics not only of the successful organization, but als o healthy local society, where MCC is anchored. Certainly participative and solidary Basque culture has also greatly contributed to MCC's success.

Mondragón Corporate Cooperativa with all its unconventional solutions and unique practices is a very interesting organization, definitely worth being observed and learned from, especially for other companies which would like to implement employee participation in management.

\section{Notes}

[1] Data for 2011, after: http://www.mondragon-corporation.com/.

[2] Report generated from the website of Instituto Nacional de Estadística: http://www.ine.es/ jaxiBD/tabla.do?per $=12 \&$ type $=$ db \&divi $=$ EPA $\&$ idtab $=866$.

[3] Data for 2011, after: http://www.konfekoop.coop/fitxategiak/Memoria\%20Actividades\%20 2011.pdf.

\section{References}

Arando, S. (2013), Efficiency in Employee-Owned Enterprises: An Econometric Case Study of Mondragon, paper presented at: Dimensions and Perspectives on Financial Participation, Helmut-Schmidt-Universität, Hamburg 2013.

Bakaikoa, B., Errasti, A., Begiristain, A. (2004), "Governance of the Mondragon Corporacion Cooperativa”, Annals of Public \& Cooperative Economics, Vol. 75, pp. 61-87. DOI: $10.1111 /$ j.1467-8292.2004.00243.x

Bakan, I., Suseno, Y., Pinnington, A., Money, A. (2004), "The influence of financial participation and participation in decision-making on employee job attitudes", International Journal of Human Resource Management, Vol. 15 No. 3, pp. 587-616. DOI: $10.1080 / 00958515042000181142$

Bławat, A., Drobny, A. (2011), Dialog Organizacyjny. Historia poszukiwań harmonijnego stylu zarzadzania w firmie xtech.pl., Oficyna a Wolters Kluwer Business, Warszawa.

Butcher, D., Clarke, M. (2002), “Organization Politics, the Cornerstone of Organization Democracy", Organization Dynamics, Vol. 31 No. 1, pp. 35-46.

Cabrera, Á., Cabrera, E.F., Ortega, J. (2001), "Employee participation in Europe”, Carlos III University Business Economics Paper, Series 2.

Cancelo, A.A. (1999), "Mondragón Corporación Cooperativa "Historia de una Experiencia”, Revista Internacional de los Estudios Vascos, Vol. 44 No. 2, pp. 323-357.

Casadesus-Masanell, R., Khanna, T. (2003), "Globalization and Trust: Theory and Evidence from Cooperatives", Harvard Business School Working Paper, No. 03-081.

Cotton, J.L., Vollrath, D.A., Froggatt, K.L., Lengnick-Hall, M.L., Jennings, K.R. (1988), "Employee participation: Diverse forms and different outcomes", Academy of Management Review, Vol. 13 No. 1, pp. 8-22. DOI: 10.2307/258351

Dachler, H.P., Wilpert, B. (1978), "Conceptual dimensions and boundaries of participation in organizations”, Administrative Science Quarterly, Vol. 23, pp. 1-39.

DOI: $10.2307 / 2392432$ 
EMPLOYEE

PARTICIPATION IN MANAGEMENT

Aleksandra Bławat
Erdal, D. (2008), Local Heroes: how Loch Fyne Oysters embraced employee ownership and business success, Penguin/Viking, London.

Grady, R. (1990), “Workplace Democracy and Possessive Individualism”, Journal of Politics, Vol. 52 No.1, pp. 146-166. DOI: 10.2307/2131423

Herzberg, F. (1959), The Motivation to Work, John Wiley and Sons, New York.

Hyman, J., Mason, B. (1995), Managing employee involvement and participation, Sage, London.

Iriazar, I., MacLeod, G. (2010), 32 claves empresariales de Mondragon, ACD, Garaia, Oñati.

Lischeron, J.A., Wall, T.D. (1975), "Employee participation: An experimental field study", Human relations, Vol. 28 No. 9, pp. 863-884. DOI: 10.1177/001872677502800906

Maslow, A. (1954), Motivation and Personality, Harper, NY.

Mazur, M. (1969), Cybernetyka a zarzqdzanie, Ministerstwo Spraw Wewnętrznych, Departament Szkolenia i Wydawnictw, Warszawa.

McGregor, D. (1960), The Human Side of Enterprise. McGraw-Hill, New York.

Meister, A. (1974), "Le participation dans les associations”, Éditions Économie et Humanisme. Les Editions Ouvrières.

Michels, R. (1915), Political Parties: A Sociological Study of the Oligarchical Tendencies of Modern Democracy, The Free Press, New York.

Mohr, L. (1977), "Authority and Democracy in Organizations", Human Relations, Vol. 10, pp. 919-947.

DOI: $10.1177 / 001872677703001005$

Pierce, J.L., Kostova, T., Dirks, K.T. (2001), "Towards a theory of psychological ownership in organizations", Academy of Management Review, Vol. 26, pp. 298-310.

DOI: $10.2307 / 259124$

Pfeffer, J. (1998), "Seven Practices of Successful Organizations", California Management Review, Vol. 40 No. 2, pp. 96-123. DOI: 10.2307/41165935

Rivera-Batiz, F.L., Rivera-Batiz, L.A. (2002), "Democracy Participation, and Economic Development: An Introduction", Review of Development Economics, Vol. 6 No. 2, pp. $135-150$.

DOI: $10.1111 / 1467-9361.00146$

Semler, R. (1998), Na przekór stereotypom. Tajemnica sukcesu najbardziej niezwykłego przedsiębiorstwa na świecie, Dom Wydawniczy ABC, Warszawa.

Stocki, R. Prokopowicz, P., Żmuda, G. (2008), „Pełna partycypacja w zarządzaniu: Tajemnica największych eksperymentów menedżerskich świata.” Oficyna a Wolters Kluwer Business, Kraków.

Stack, J., Burlingham, B. (1994), The Great Game of Business, Currency Press, New York.

Whyte, W.F. (1995), "Learning from the Mondragón cooperative experience", Studies in Comparative International Development, Vol. 30 No. 2, pp. 59-67.

Warr, P.B. (2007), Work, Happiness, and Unhappiness, Routledge, New York.

Wright, S., Greenwood, D., Boden, R. (2011), "Report on a field visit to Mondragón University: a cooperative experience/experiment", Learning and Teaching: the International Journal of Higher Education in the Social Sciences, Vol. 4 No. 3, pp. 38-56. 